We also found an increased risk of cancer of the peritoneum and other digestive organs. One explanation for this association is that some of the observed cancers in this category were misclassified testicular or extragonadal germ cell tumours. Extragonadal germ cell tumours have been associated with testicular carcinoma in situ, ${ }^{28}{ }^{29}$ suggesting a common aetiology with testicular cancer.

From a public health perspective, our study provides some reassurance to men identified with abnormal semen characteristics, despite the increased relative risks. The absolute excess of cancers is about 36 cases per 32442 men followed for 297750 person years. The absolute increase in risk for the individual is therefore very small.

Contributors: RJ was responsible for the study design, data collection, statistical analysis, interpretation, and reporting and is the guarantor. $\mathrm{EB}, \mathrm{GE}, \mathrm{JH}, \mathrm{JHO}, \mathrm{NES}$, and $\mathrm{HM}$ contributed to the study design, data collection, interpretation, and reporting.

Funding: Danish Research Councils.

Competing interests: None declared.

1 Carlsen E, Giwercman A, Keiding N, Skakkebæk NE. Evidence for decreasing quality of semen during past 50 years. BMJ 1992;305:609-13. Swan SH, Elkin EP, Fenster L. Have sperm densities declined? A reanalysis of global trend data. Environ Health Perspect 1997;105:1228-32.

3 Coleman MP, Esteve J, Damiecki P, Arslan A, Renard H. Trends in cancer incidence and mortality. Lyons: International Agency for Research on Cancer, 1993. (IARC Scientific Publication No 121.)

4 Forman D, Møller H. Testicular cancer. Cancer Surv 1994;19-20:323-41.

5 Adami HO, Bergström R, Mohner M, Zatonski W, Storm H, Ekbom A, et al. Testicular cancer in nine northern European countries. Int J Cancer 1994;59:33-8.

6 James WH. Secular trends in monitors of reproductive hazard. Hum Reprod 1997;12:417-21.

7 Møller H. Trends in sex-ratio, testicular cancer and male reproductive hazards: are they connected? APMIS 1998;106:232-39.

8 Møller H, Skakkebæk NE. Risk of testicular cancer in subfertile men: case-control study. BMJ 1999;318:559-62.

9 Swerdlow AJ, Huttly SR, Smith PG. Testis cancer: post-natal hormonal factors, sexual behaviour and fertility. Int J Cancer 1989;43:549-53.

10 Jabsen R, Antoniades B, Bostofte E, Engholm G, Hansen J, Skakkebaek $\mathrm{NE}$, et al. Fertility and offspring sex ratio of men who develop testicular cancer: a record linkage study. Hum Reprod 2000;15:1958-61.

11 Bostofte E, Serup J, Rebbe H, Interrelations among the characteristics of human semen, and a new system for classification of male infertility. Fertil Steril 1989;41:95-102.
12 World Health Organization. Laboratory manual for examination of human semen and sperm-cervical mucus interaction. Cambridge: Cambridge University Press, 1999.

13 Nijman JM, Schraffordt Koops H, Kremer J, Willemse PHB, Sleijfer DT, Oldhoff J. Fertility and hormonal function in patients with nonseminomatous tumor of the testis. Arch Andrology 1985;14:239-46.

14 Carroll P, Whitmore WF Jr, Herr HW, Morse MJ, Sogani PC, Bajorunas D, et al. Endocrine and exocrine profiles of men with testicular tumors before orchidectomy. J Urol 1987;137:420-3.

15 Storm HH. The Danish Cancer Registry, a self-reporting national cancer registration system with elements of active data collection. Lyons: International Agency for Research on Cancer, 1991:220-36. (IARC Scientific Publication No 95.)

16 Bostofte E, Bagger P, Michael A, Stakemann G. Fertility prognosis for infertile men: results of follow-up study of semen analysis in infertile men from two different populations evaluated by the Cox regression model. Fertil Steril 1990;54:1100-6.

17 Coleman M, Douglas A, Hermon C, Peto J. Cohort study analysis with a Fortran computer program. Int J Epidemiol 1986;15:134-7.

18 Berthelsen JG, Skakkebæk NE. Gonadal function in men with testis cancer. Fertil Steril 1983;39:68-75.

19 Møller H. Clues to the aetiology of testicular germ cell tumours from descriptive epidemiology. Eur Urol 1993;23:8-13

20 Bergström R, Adami HO, Mohner M, Zatonski W, Storm H, Ekbom A, et al. Increase in testicular cancer incidence in six European countries: a birth cohort phenomenon. J Natl Cancer Inst 1996;88:727-33.

21 Wanderås EH, Grotmol T, Fossa SD, Tretli S. Maternal health and preand perinatal characteristics in the etiology of testicular cancer: a prospective population- and register-based study on Norwegian males born between 1967 and 1995. Cancer Causes Control 1998;9:475-86.

22 Møller H, Skakkebæk NE. Testicular cancer and cryptorchidism in relation to prenatal factors: case-control studies in Denmark. Cancer Causes Control 1997;8:904-12.

23 United Kingdom Testicular Cancer Study Group. Aetiology of testicular cancer: association with congenital abnormalities, age at puberty, infertility, and exercise. BMJ 1994;308:1393-9.

24 Møller H, Prener A, Skakkebæk NE. Testicular cancer, cryptorchidism, inguinal hernia, testicular atrophy, and genital malformations: Case control studies in Denmark. Cancer Causes Control 1995;7:264-74.

25 Skakkebæk NE, Berthelsen JG, Giwercman A, Müller J. Carcinoma-in-situ of the testis: possible origin from gonocytes and precursor of all types of germ cell tumors except spermacytoma. Int J Andrology 1987;10:19-28.

26 Sharpe RM, Skakkebaek NE. Are oestrogens involved in falling sperm counts and disorders of the male reproductive tract? Lancet $1993 ; 341: 1392-5$.

27 Henderson BE, Benton B, Jing J, Yu MC, Pike MC. Risk factors for cancer of the testis in young men. Int J Cancer 1979;23:598-602.

28 Daugaard G, Rorth M, von der Maase H, Skakkebaek NE. Management of extragonadal germ-cell tumors and the significance of bilateral testicular biopsies. Ann Oncol 1992;3:283-9.

29 Daugaard G, von der Maase H, Olsen J, Rorth M, Skakkebaek NE, Carcinoma-in-situ testis in patients with assumed extragonadal germ-cell tumours. Lancet 1987;ii:528-30.

(Accepted 19June 2000)

\title{
Towards evidence based circumcision of English boys: survey of trends in practice
}

\author{
A M K Rickwood, S E Kenny, S C Donnell
}

Department of Urology, Alder Hey Children's Hospital, Liverpool L12 2AP A M K Rickwood consultant urologist

Department of Child Health, Institute of Child Health, University of Liverpool, Alde Hey Children's

Hospital

S E Kenny

lecturer in paediatric surgery

continued over

BMJ 2000;321:792-3

\section{Introduction}

Although the proportion of English boys circumcised for medical reasons fell from 35\% in the early 1930s to $6.5 \%$ by the mid- $1980 \mathrm{~s}$, even latterly it was argued that some two thirds underwent the procedure unnecessarily, ${ }^{1}$ a judgment consistent with practice in Scandinavia, where less than $2 \%$ of boys are circumcised. ${ }^{2}$ Has any further change occurred in English practice, and, if so, is this evidence based? We examined trends in the catchment population of a children's hospital, in its surrounding region, and in England as a whole.

\section{Subjects, methods, and results}

The study was confined to medically indicated operative circumcisions. Statistics for circumcisions for the NHS, including diagnostic codings, were obtained for the Mersey region and its health districts for 1975-97 and for England for 1984-6 and 1990-8. Data for 1996-8 may slightly underestimate the number of procedures performed. ${ }^{3}$ Corresponding population figures were supplied by the Office for National Statistics. The catchment population of the Liverpool children's hospital has been taken as that of the Liverpool and Sefton health districts.

During the study period, similar proportions of procedures were indicated for phimosis in the Mersey region (89.5\%) and in England as whole (90.2\%). Rates of circumcision, overall and stratified by age, are shown in the figure. During the earlier years these rates differed little between the Mersey region and the Liverpool children's hospital, and by the mid-1980s both overall rates closely matched the figure for all 

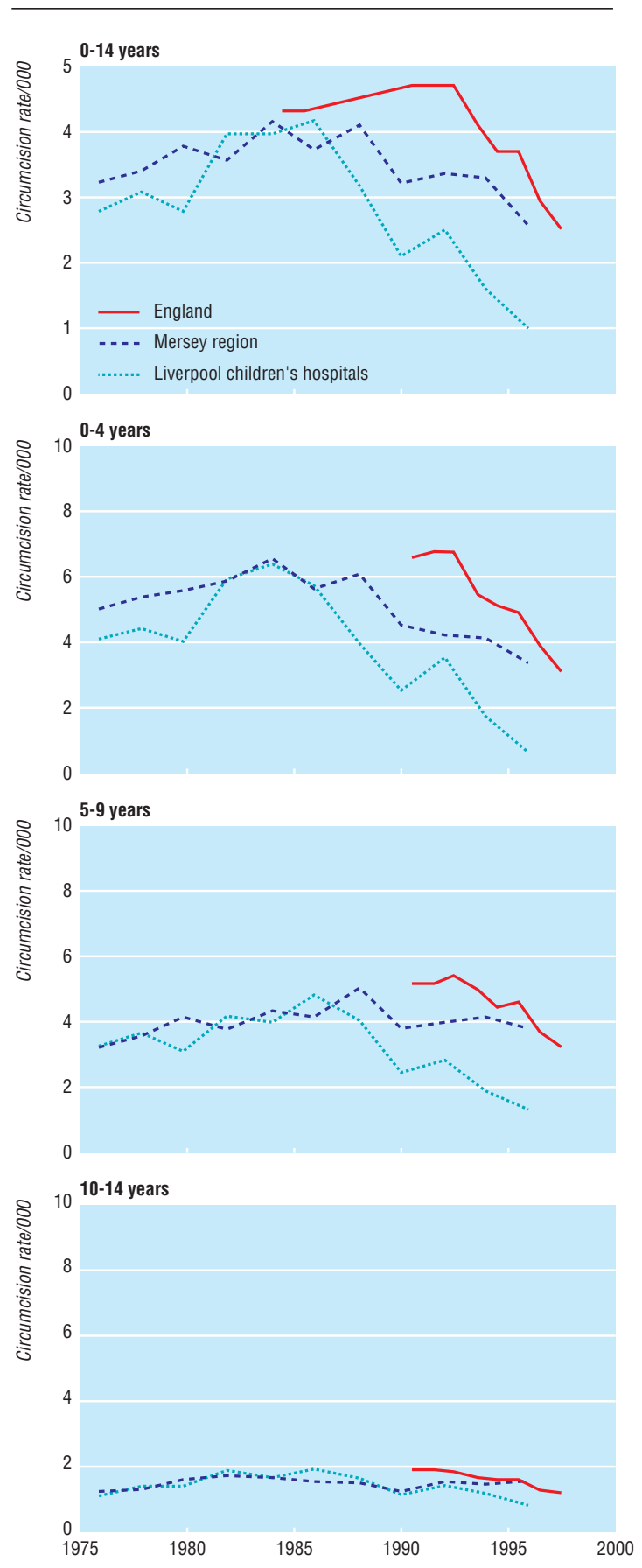

Rates of circumcision (per 1000 boys/year), England (1984-6 and 1990-8), Mersey region (1975-97), and Liverpool children's hospitals (1975-97), overall and in three age ranges. (Figures for the Mersey region and the Liverpool children's hospitals are presented as two-year means)

England. Since then downward trends have progressively emerged, most conspicuously among boys aged $0-4$ years, but less so among 5-9 year olds. Rates among 10-14 year olds have remained almost static and have shown negligible geographical variation.

If the most recent overall circumcision rate (about 12200 procedures annually) remained unchanged, $3.8 \%$ of English boys would be circumcised by their 15th birthday. Among boys resident in the Liverpool and Sefton health districts the proportion would be $1.5 \%$.

\section{Comment}

Too many English boys, especially those under 5 years of age, are still being circumcised because of misdiagnosis of phimosis. What is phimosis? At birth, the foreskin is almost invariably non-retractable, but this state is transient and resolves in nearly all boys as they mature. Such normality, with an unscarred and pliant preputial orifice, is clearly distinguishable from pathological phimosis, a condition unambiguously characterised by secondary cicatrisation of the orifice, usually due to balanitis xerotica obliterans. ${ }^{4}$ This problem, the only absolute indication for circumcision, affects some $0.6 \%$ of boys, ${ }^{4}$ peaks in incidence at 11 years of age, and is rarely encountered before the age of $5 .^{14}$ On this basis, the steeply falling circumcision rates among 0-4 year olds are readily explicable and lesser declines among 5-9 year olds are consistent with this group containing a proportion with pathological phimosis. Among 10-14 year olds, pathological phimosis is the predominant indication, ${ }^{1}$ thereby explaining the static rates of circumcision throughout England and their lack of geographical variation.

Recent trends are therefore consistent in direction, but not in extent, with the evidence base. Strictly, only some $0.6 \%$ of boys with pathological phimosis need to be circumcised, ${ }^{4}$ although more relaxed criteria would allow for a similar proportion affected by recurrent balanoposthitis. ${ }^{5}$ None the less, the trend towards evidence based practice already pays dividends. Circumcision costs about $£ 500$ as a daycase procedure, and some 10000 fewer circumcisions in 1997-8 than in 1992-3 release $£ 5 \mathrm{~m}$ for other purposes. A reduction in the proportion of English boys circumcised to an attainable target of $2 \%$ would make for about 6000 fewer circumcisions each year, with a corresponding saving of $£ 3 m$.

We thank Mr D Gilbert and Ms P Basuroy of the Department of Health, Mr G Pellegrini of the Liverpool Health Authority, and Ms A Humber of the Office for National Statistics for their boundless patience in supplying data on circumcision and population data.

Contributors: AMKR had the original idea for the study and participated in data collection and analysis. SCD helped in study design and data collection. SEK helped in data collection and analysis. The paper was jointly written by AMKR and SEK. AMKR is the guarantor for the study.

Competing interests: None declared.

1 Rickwood AMK, Walker J. Is phimosis over diagnosed in boys and are too many circumcisions performed in consequence? Ann R Coll Surg Engl 1989;71:275-7.

2 Frisch M, Friis S, Krüger Kjaer S, Melbye M. Falling incidence of penile cancer in an uncircumcised population (Denmark 1943-90). BMJ 1995;311:1471.

3 Kenny N, McFarlane A. Identifying problems with data collection at a local level: a survey of NHS maternity units in England. BMJ 1999;319:619-22.

4 Shankar KR, Rickwood AMK. The incidence of phimosis in boys. $\mathrm{Br} J$ Urol 1999;84:101-2

5 Escala JM, Rickwood AMK. Balanitis. Br J Urol 1989;63:196-7. (Accepted 25 May 2000)

\section{Endpieces}

\section{Wise words}

They certainly give very strange names to diseases. Plato, 427-347 вс
Department of Paediatric Surgery, Birmingham Children's Hospital, Birmingham B16 8ET

S C Donnell consultant paediatric surgeon

Correspondence to: A M K Rickwood 